of those expeditions which appeared previously in the two volumes of "Spitsbergen Papers". The volume shows the extent of valuable work that can be done by a small summer expedition to polar regions, especially when the sphere of work is well defined.

\section{Map of Central America and West Indies}

A USEFUL map, embodying the latest information, of Mexico, Central America and the West Indies on a scale of 90 miles to an inch is published by the National Geographic Society at Washington. It is in the main a political map and relief is shown only by hachures, but a number of spot heights are given. Railways and the main highways are shown, and there are many names. Insets show the more important West Indian islands on larger scale. The colour printing is very clear.

\section{Eradication of Prickly Pear in Queensland}

THE reclamation in Queensland of land formerly infested with prickly pear (Opuntia spp.) steadily continues. During the year which ended on June 30, $1934,5,300,000$ acres were made available for selection or for lease under developmental tenure. The total area reclaimed and thrown open for settlement during the past three years is $13,750,000$ acres, or approximately 20 per cent of the whole infested region.

\section{International Congress of Americanists}

THE twenty-sixth session of the International Congress of Americanists, which was to have taken place during November in Seville, had to be post. poned owing to financial and political difficulties in Spain. The work of organisation is, however, well advanced and it is hoped that it may still be possible to hold the Congress early in 1935 . It is unfortunate that the deliberations of this body, which are invariably of great scientific interest to students of the cultures of aboriginal America, should be subjected. to interruption through political unrest. It will be remembered that when the Congress last met in La Plata at the close of 1932, conditions were anything but favourable to an international scientific assembly, and, indeed, had it not been for a certain disorganisation arising out of these conditions, it is probable that the invitation of Great Britain would have been accepted and the Congress would have met in London in close association with the First International Congress of Ethnological Sciences in August last.

\section{Imperial Botanical Conference}

AN Imperial Botanical Conference, commencing on August 28 and lasting two to three days, according to the programme which may finally be arranged, will be held in London this year. The subjects set down for discussion are of general interest to Empire botanists, and include such topics as pasture research within the Empire, the ecology of tropical forests, the application of ecological methods to the study of native agriculture, problems of fruit storage and transport with special reference to tropical conditions, the furtherance of schemes for the closer co-ordination of botanical research within the Empire, etc. It is hoped that this Conference will furnish a convenient meeting ground for home and overseas botanists who are on their way to attend the International Botanical Congress which meets at Amsterdam in the week following. The chairman of the Organising Committee of the Conference is Sir Arthur Hill, director of the Royal Botanic Gardens, Kew, and the honorary secretary is Prof. W. Brown, Imperial College of Science and Technology, South Kensington, London, S.W.7, from whom further particulars may be obtained.

\section{Announcements}

Mr. Francis N. Ratcliffe, assistant in the Natural History Department, University of Aberdeen, has been appointed to the head-quarters staff of the Council of Scientific and Industrial Research, Commonwealth of Australia.

THE first volume of the new international botanical yearbook to be known as Chronica Botanica, to which reference was made in NATURE of September 29 , p. 493 , will be published shortly. Heads of botanical institutions, etc., who have received the questionnaire are therefore requested to return it to the publisher, Fr. Verdoorn, P.O. Box 8, Leyden, Holland, as soon as possible. Answers should reach Leyden before January 10 from Europe, January 20 from the United States and Canada, and January 30 from other parts of the world.

A RECENTLY issued catalogue of books and periodicals on natural history for sale by Bernard Quaritch, Ltd., covers zoology, geology and palæontology, and contains a good selection comprising more than 2,000 items.

Applicatrons are invited for the following appointments, on or before the dates mentioned :-A lecturer in science and hygiene in the Liverpool City Technical School for Women and F. L. Calder College of Domestic Science-The Director of Education, 14 Sir Thomas Street, Liverpool, 1 (Jan. 7). An assistant lecturer in pharmacy in the Technical College, Bradford-The Director of Education, Town Hall, Bradford (Jan. 15). Three chemists at the Rubber Research Institute of Malaya--The Secretary, London Advisory Committee for Rubber Research (Ceylon and Malaya), Imperial Institute, S.W.7 (Jan. 18). Assistant lecturers in metallurgy in the University of Birmingham-The Secretary (Jan. 21). Two research bacteriologists in the Medical Research Department of the Government of India-The High Commissioner for India, General Department, India House, Aldwych, W.C.2 (Jan. 26). A bacteriological research assistant to the Metropolitan Water Board-The Clerk, 173, Rosebery Avenue, E.C.1 (Jan. 26). A research assistant in tissue culture and assistant lecturer in histology at the University of Birmingham - The Secretary (Feb. 1). A lecturer in chemistry at University College, University of Rangoon-The Secretary, Universities Bureau of the British Empire, 88A Gower Street, London, W.C.I. 